\title{
Birth, Death, and Rebirth: Reconstruction of architecture in Ruskin's writings
}

\author{
Anuradha Chatterjee
}

\section{Reconstructions: a brief overview}

The emergence of the practice of restoration in eighteenth-century France and Britain was a response to the destruction of buildings due to fire, war, revolutions, and neglect, complemented by the desire to consolidate cultural heritage, and thus national identity. John Ruskin (1819-1900) responded to the erosion of the historical fabric in European cities, particularly in Venice, which suffered significant damage to its built fabric during the six-month siege and aerial bombardment of the city by Austrian forces in 1848 (Mallgrave 2005: 121). It is well known that whilst Ruskin vehemently rejected restoration, he advocated preservation; in this his influential diatribe was simultaneously radical and conservative. Development of this approach can be found in his earlier writings on art, for example in Modern Painters (1843), as prefaced in the five dense pages of "Lamp of Memory" fronting The Seven Lamps of Architecture (1849), and followed up in his 1854 pamphlet titled "The Opening of the Crystal Palace". The following passage from The Seven Lamps of Architecture is indicative:

Accept it as such, pull the building down, throw its stones into neglected corners, make ballast of them, or mortar, if you will; but do it honestly, and do not set up a Lie in their place. And look that necessity in the face before it comes, and you may prevent it ... Take proper care of your monuments, and you will not need to restore them ... Watch an old building with an anxious care; guard it as best you may, and at any cost, from every influence of dilapidation ... bind it together with iron where it loosens; stay it with timber where it declines; do not care about the unsightliness of the aid: better a crutch than a lost limb. (Ruskin 1849/1903-1912: 244-245)

The recommendation to delay physical deterioration was to be complemented by parallel practices of collection and documentation. This was exemplified by Ruskin's own engagement with writing as word painting, drawings, producing and collecting via the then-new photographic technique of daguerreotypes, and the taking of plaster casts of architectural details and ornament (Figures 1 and 2). As he argued, if the "evil day [of dilapidation] must come at last; [...] let it come declaredly and openly” (Ruskin 1849/1903-1912: 245). In the meantime, he proposed, the combined acts of care, accurate observation, and material recording via different documentary techniques would compensate for the eventual and anticipated disappearance of historic buildings.

Lowenthal (1985) and Hunt (1978) reiterate the importance of ruins in the picturesque aesthetic and Ruskin's appreciation of this view $(157,796)$.

2 As Maximilian L. Ferro explains: "'Antiscrape,' a word actually coined in the late 1870 's to describe the newly-founded Society for the Protection of Ancient Buildings (SPAB 1877), is symbolic of the attitude that historic buildings should be left alone." Ferro further explains that this practice entailed the rejection of the earlier practice of restoration advanced by George Gilbert Scott, which "involved the scraping of plaster to re-expose interior stonework, and [hence] 'scraping' became synonymous with restoration" (1985: 22).
Ruskin's views on restoration have been characterised as falling into two distinct critical realms: firstly, one based upon commentary that upholds the "sublimity of the rents, or fractures, or stains, or vegetation ... [that] assimilates the architecture with the work of Nature", and thereby focused on ruins and the picturesque (Ruskin 1849/1903-1912: 249). ${ }^{1}$ The second critical concern was with an overarching pursuit of truth and authenticity. This informed William Morris' interpretation of Ruskin and was influential in the establishment of the Society for the Protection of Ancient Buildings (SPAB), which in turn fostered the uncritical truism that new work cannot replicate or supplant older work, promoting what came to be known as the Anti-Scrape philosophy. ${ }^{2}$ Nevertheless, these perspectives miss the fundamental anti-materialism of Ruskin's views. 


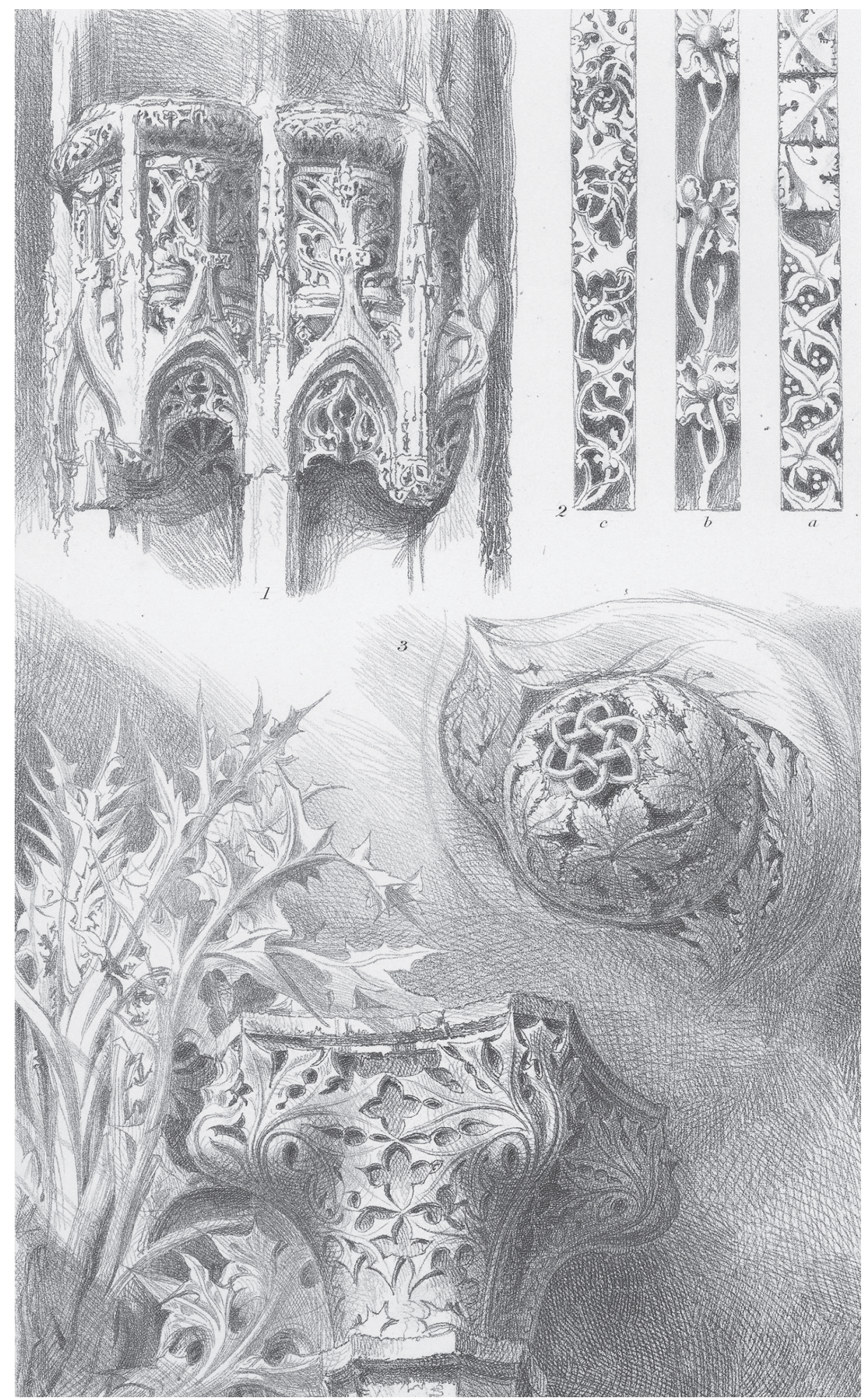

Fig. 1 John Ruskin (1819-1900). Ornaments from Rouen, St. Lô, and Venice. [Source The Seven Lamps of Architecture, 6th edn, George Allen, Orpington, Kent, 1889, plate 1, p. 27] 



Fig. 2 John Ruskin (1819-1900). Pierced ornament from Lisieux, Bayeux, Verona, and Padua. [Source The Seven Lamps of Architecture, plate 7, p. 95] 


\section{Deconstructing Ruskin on reconstruction}

It is argued here that Ruskin's views on restoration are reflective of deeper concerns with the notion of life. By this reading, buildings did not merely go into a state of ruin or disappear - they passed away. Mark Swenarton notes that this was due to Ruskin's aligning with German Romantic thinkers like Goethe, who perceived that "art was the expression of the creative human spirit and the work of art was matter endowed with spirit" (Swenarton 1989: 3). Accordingly, in Stones of Venice (1851-1853) Ruskin notes, "art is valuable or otherwise, only as it expresses the personality, activity and living perception of a good and great human soul" (1989: 10). Unlike Romanticism's allusion to elusive and often invisible signs of life, Ruskin viewed life as having a stronger corporeal energy and presence. The Seven Lamps characterises ornament as the "written or sealed impression of a thing sought out [hence ...] it is the shaped result of inquiry and bodily expression of thought" (1849/1903-1912:155). In fact, Ruskin believed that nations and societies that did not have an enduring material culture, for which architecture was exemplary, could be said to "die daily" (1849/1903-1912: 224).

The notion then that a building dies was not merely allegorical. In The Seven Lamps, Ruskin urges: "Do not let us deceive ourselves in this important matter; it is impossible, as impossible as to raise the dead, to restore anything that has ever been great or beautiful in architecture." (1849/1903-1912: 244) He adds: "You may make a model of a building as you may of a corpse, and your model may have the shell of the old walls within it as your cast might have the skeleton." (244) In another instance, he notes "that architecture and painting can be restored" no more than "the dead can be" (1854/1903-1912: 429).

Even though a classical idealisation of the human figure and the nineteenth century rationalisation of the living body are sustained in Ruskin's writing, the emphasis is on animation, not figuration. Hence, restoring a dead building was inconceivable, for the issue had little to do with a reconstruction of the physical, but with the sustaining or reviving of the spirit. Zombie-like, the restored building risks manifesting a form of architectural uncanny, as it hovers indeterminately between animation and lifelessness, between historical and present time.

Architecture's demise occurred due to what could be considered cosmetic damage. Ruskin rarely noted the structural failure or damage to key internal parts of historic buildings, and his account of surface decay outweighed his observations of these failures. For him it was the disruption of the surface that was most calamitous. As he put it, "What copying can there be of surfaces that have been worn half an inch down? The whole finish of the work was in the half inch that is gone." (1849/1903-1912: 242) The removal of ornament and cladding from the building was akin to the mutilating blows to the fleshy surface of the body that prompted its eventual demise. In fact, as he further added, the death of architecture was reversible: "That which I have above insisted upon as the life of the whole, that spirit which is given only by the hand and eye of the workman, can never be recalled. [However a]nother spirit may be given by another time, and it is then a new building; but the spirit of the dead workman cannot be summoned up, and commanded to direct other hands, and other thoughts." (1849/1903-1912: 242) He is suggesting that the cladding and ornamentation be completely ripped off and the structure re-clad. In this way the building is 'reborn'. To the extent that a different building, a new building, would emerge, at stake for Ruskin, clearly, were questions of spiritual, not biological life. 
Ruskin's theory of spiritual life owes a debt to Scottish satirical writer, essayist, and critic, Thomas Carlyle (1795-1881). As Herbert Sussman explains, for Carlyle, "England's mechanisation appeared bound to philosophical mechanism, the occupation with material means rather than spiritual ends." (Sussman 1968: 15) In "Signs of the Times" (1829), Carlyle noted the blossoming of physical sciences paralleled by the disappearance of metaphysical and moral sciences (103). He argued that the physical sciences are concerned with the "material, the immediately practical, [and] not the divine and [the] spiritual" (111). As the body is colonised by empirical knowledge, the only way the soul is able to overcome its subjection to material measure is through the expressiveness of clothing. In his parodic novel Sartor Resartus, Carlyle went on to explore how clothes express a hidden inner idea. Regarded as the precedent of modern dress studies, Sartor notes that clothes are the "grand tissue of all tissue" and is what "man's soul wears as its outmost wrappage and overall" (1833-1834/1983: 2). Beneath this, "his whole other ... tissues are included and screened, his whole faculties work, his whole self lives, moves, and has its being” (1833-1834/1983: 2). Significantly, clothes are given, not just a corporeal quality, but an importance greater than the body. Apparel attributes meaning and, therefore, life to the body. Through it the soul finds direct, exterior, and autonomous expression.

Applying these notions from Carlyle's Sartor Resartus, Ruskin not only undertook extensive documentation and study of drapery and draped figures, he also suggested that architecture too could be understood to have a body and a soul. Ruskin notes that like the human body, architecture too consists of a lower (body) and a higher (soul) element. The lower, bodily element is comprised of the "technical" or the "constructive" aspects of the building. The higher, spiritual element is given by the "imaginative" or the "reflective" components found in the veneer of ornamentation. As such it masks and transforms the bodily foundation of the building while giving play, in the manner of a textile fabrication, to its essential character (Ruskin 1849/1903-1912: 20-21).

Fig. 3 Ca' d'Oro (Palazzo Santa Sofia), Grand Canal, Venice. [Photo: author, 2004]

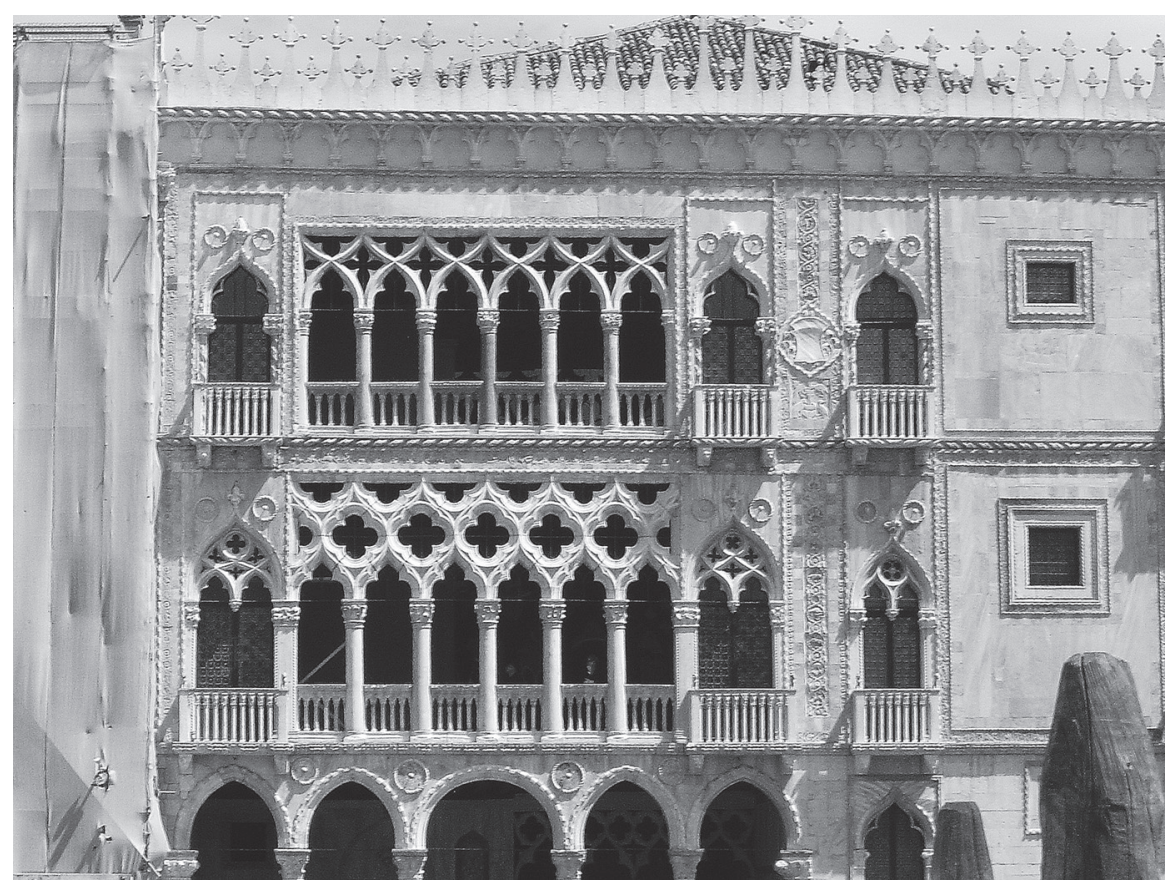


Across Ruskin's writings, the recasting of ornamental veneer as drapery and textile was a recurrent theme. For example, as Ruskin saw it, the polychromatic surface of the Baptistery of Florence turns the attention of the viewer away from the structural elements, the organisation of space, and the building's daily use, expressing instead a pointed disparity between surface dressing and the bodily form. Screens, tracery, openings, inlaid surfaces, and low relief ornament in medieval buildings like Ducal Palace and Ca D’Oro (Figs. 3 \& 4) are similarly recast as woven and knitted fabrics. Through the use of descriptive metaphors like cutting, lifting, shrinking, and gathering, Ruskin effectively converts the tectonic language of architecture into a language of tailoring and upholstering. ${ }^{3}$

Moreover, this dress-like veneer was understood to be infused with life through the creative labour of the craftsperson, who simultaneously invested body, soul, and intellect into its material expression. Yet in Ruskin's theory of creative labour it was the creativity of men that was privileged, for it was only through male hands that the imagination was synthesised with the strenuous and controlled action of a muscular body. The hand alone bestowed masculine authority and signature effects into building materials. Hence in architecture, what Ruskin sought was the residual traces of the "toil of manly hand and thought", the "life and accent of the hand", and the "masculine handling" of malleable material form (1849/1903-1912: $104,214,216)$. Only through the intervention of the venerated craftsperson does the "inert substance" of architecture receive its "dignity and pleasurableness in the utmost degree", and only through them is a "vivid expression of the intellectual life” of the building given (Ruskin, 1849/1903-1912: 190-191).

Ruskin's emphasis on the mind and the hand of the male architect/craftsperson that moulded and ordered the building material can be considered through feminist thinking on the disavowal of sexualised matter in procreation and discourses of creativity. To this end, Ruskin's theory of creative labour is reflective of the male desire to view his image in the mirror of the female body. ${ }^{4}$ This image becomes legible through the rather elusive trace of imperfection of finish and inaccuracy of detail. The trope of masculine creativity was also associated with the Victorian drive to "construct a new form of manhood and a new masculine poetic for the industrial age” (Sussman 1995: 1).

It was not enough merely to leave a trace. Its boundaries needed to be policed and ownership defended. As Ruskin prompts in relation to the built remnants:

We have no right to touch them. They are not ours. They belong partly to those that built them ... The dead still have their right in them ... What we have ourselves built we are at liberty to thrown down; but what other men gave their strength and wealth and life to accomplish, their right does not pass away with their death. (Ruskin 1849/1903-1912: 245)

In the encounter then between old and new work, a violation of this right was considered far more destructive than actual physical deterioration. Repairs were hence termed "fatal" because they were considered to be the "most total destruction which a building can suffer: a destruction out of which no remnants can be gathered" (Ruskin 1849/1903-1912: 242 \& 1854/1903-1912: 423). More than material, the destruction at stake was a shattering of the toiled privilege of the authorial male self by the imposition of another's vision.

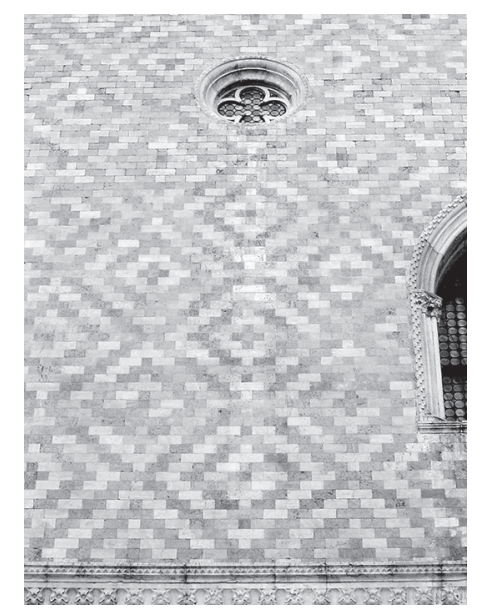

Fig. 4 Chequered cladding and window opening, Ducal Palace, Venice, Piazzetta side. [Photo: author, 2004]

\footnotetext{
3 These ideas are discussed in detail in Chatterjee (2009a), and the argument of Ruskin's adorned wall veil is developed in Chatterjee (2008).

4 For a discussion of Ruskin's feminisation of architecture, see Chatterjee (2009b: 146).
} 


\section{Reconstructing theoretical radicalisms}

Taking into account recent recontextualisations of Victorianism within the broader cultural history of modernity, Ruskin's rejection of restoration shows itself to be, not just conservative and reactionary, but advances at least three prominent cultural ambitions, which in conclusion can be summarised thus:

Firstly, Ruskin's views suggest an aversion to mortality by seeking out novel forms of immortality. In Lectures On Architecture and Painting (1854) he noted that the "dead" had intended their works for "immortality" (1854/1903-1912: 99). In "Review of Lord Lindsay's Sketches of the History of Christian Art” (1847), he notes that the spirit is the "immortal principle", and it is in the integrated and cooperative application of the three faculties of the body that it is able to become "worthy of eternal life" (1847/1903-1912: 178, 179). Architecture represents a conditional and contingent kind of immortality. Whilst it exceeds the duration of the human life that brought it into being, it also eventually dies a natural death. Ruskin's theory imparts to the building a palpable living presence (albeit fleeting), whilst establishing immortality, and re-defining the new purpose of architecture as that of fostering the act of living. 5

Secondly, Ruskin's criticism of restoration takes ornament as more than a supplemental object. Thought as a mode of craft - not as the action of design - was seen as the representative of lapsed time. This recognition refigured ornament as a living practice, seeing in it a discrete, non-replicable event, one that could only be succeeded by a subsequent event. In locating the essence of architecture in ornament, the rejection of restoration belatedly promoted new work and instigated the notion of architecture as event. These ideas find resonance with recent considerations about the performativity of gender, class and sexuality, indeed identity, in Victorian culture. They no less foreshadow contemporary interest in architecture as performance. By placing this particular emphasis on the role and performance of temporality in built work, Ruskin's views subtly challenged the materialist orientations that dominated nineteenth-century philosophical thought.

Thirdly, Ruskin's writings eschew any recuperation of the authentic, seeing such a quest as both undesirable and impossible. As Ruskin claimed, "however careful, however laboured, an imitation still, a cold model” (1849/1903-1912: 243). Moreover, Ruskin's criticism of restoration was not simply aesthetic, but in essence philosophical. It foreshadowed Walter Benjamin's argument that the "presence of the original is the prerequisite of the concept of authenticity", and hence "authenticity is not reproducible" (1955/1968: 220, 243). Ruskin too favoured the mechanical reproduction of buildings (via daguerreotypes and drawings) over manual reproduction (as the questionable labour of restoration). Ruskin's allegory of life, death, and rebirth, meant reaching past the impasse of the authentic, the original, the true. The possibility of the return of the original is disabled forever. While the authentic could not be reproduced, it could at least be created anew.

5 For discussion of the architectural body in Arakawa and Gins' works, see Kennedy (2006) and Danto (1997). 


\section{References}

Benjamin, W. \& Arendt, H. (Ed.), (1969). Illuminations (H. Zohn, Trans.). New York, N.Y.: Schocken Books Inc. (Original work published 1955).

Carlyle, T. (1858). Signs of the times. In The collected works of Thomas Carlyle, vol. 3. London: Chapman and Hall. Retrieved from http://www.victorianweb.org/authors/carlyle/signs1.html (Original work published 1829).

Carlyle, T. \& Bloom, H. (Ed.), (1983). Sartor Resartus. New York, NY: Chelsea House. (Original work published 1833-34).

Chatterjee, A. (2009a). Tectonic into textile: John Ruskin and his obsession with the architectural surface. Textile $7(1), 68-97$.

Chatterjee, A. (2009b). John Ruskin and female body as the theoretical precondition for architecture Fabrications: Journal of the Society of Architectural Historians, Australia and New Zealand 19 (1), 140-161.

Chatterjee, A. (2008). The troubled surface of architecture: John Ruskin, human body, and external walls. (Unpublished doctoral dissertation). University of New South Wales, Sydney. Danto, A. C. (1997). Arakawa and Gins. The Nation, 18, 31-34.

Ferro, M. L. (1985). Scrape vs. antiscrape: A modern American perspective. APT Bulletin 17 (3/4), 21-25.

Hunt, J. D. (1978). Ut Pictura Poesis, the picturesque, and John Ruskin. MLN: Modern Language Notes 93 (5), 794-818.

Kennedy, J. (2006). Gins, Arakawa and the undying community. Culture Machine 8. Retrieved from http://www.culturemachine.net/index.php/cm/article/viewArticle/44/52

Lowenthal, D. (1985). The past is a foreign country. Cambridge: Cambridge University Press.

Mallgrave, H. F. (2005). Modern architectural theory: A historical survey, 1673-1968. New York: Cambridge University Press.

Ruskin, J. (1903-1912). The seven lamps of architecture. In E. T. Cook \& A. Wedderburn (Eds.), The works of John Ruskin (Library Edn, Vol 8). London: George Allen. (Original work published 1849).

Ruskin, J. (1903-1912). Stones of Venice, Vol 1. In E. T. Cook \& A. Wedderburn (Eds.). The works of John Ruskin (Library Edn, Vol 9). London: George Allen. (Original work published 1851).

Ruskin, J. (1903-1912). Lectures on architecture and painting. In E. T. Cook \& A. Wedderburn (Eds.). The works of John Ruskin (Library Edn, Vol 12, pp. 7-164). London: George Allen. (Original work published 1854).

Ruskin, J. (1903-1912). The opening of the Crystal Palace. In E. T. Cook \& A. Wedderburn (Eds.). The works of John Ruskin (Library edn, Vol 12, pp. 417-432). London: George Allen. (Original work published 1854).

Sussman, H. L. (1968). Victorians and the machine: The literary response to technology. Cambridge, Mass: Harvard University Press.

Sussman, H. L. (1995). Victorian masculinities: Manhood and masculine poetics in early Victorian literature and art. Cambridge \& New York: Cambridge University Press.

Swenarton, M. (1989). Ruskin and the nature of Gothic. In Artisans and architects: The Ruskinian tradition in architectural thought (pp.1-31). Basingstoke: Macmillan. 